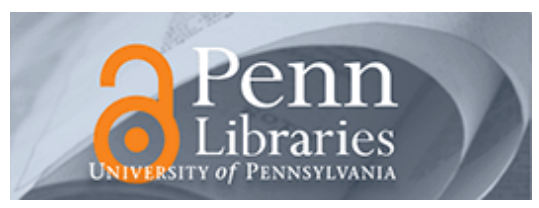

Manuscript Studies

Volume 1

Issue 2 Fall 2017

Article 7

2017

\title{
Medieval Origins Revealed by Modern Provenance: The Case of the Bywater Missal
}

Peter Kidd

pjkidd@gmail.com

Follow this and additional works at: https://repository.upenn.edu/mss_sims

Part of the Medieval Studies Commons

\section{Recommended Citation}

Kidd, Peter (2017) "Medieval Origins Revealed by Modern Provenance: The Case of the Bywater Missal," Manuscript Studies: Vol. 1 : Iss. 2 , Article 7.

Available at: https://repository.upenn.edu/mss_sims/vol1/iss2/7

This paper is posted at ScholarlyCommons. https://repository.upenn.edu/mss_sims/vol1/iss2/7

For more information, please contact repository@pobox.upenn.edu. 


\title{
Medieval Origins Revealed by Modern Provenance: The Case of the Bywater Missal
}

\author{
Abstract \\ This essay works backwards and forwards from a few known points in the history of an early 13th-century \\ illuminated missal at the Bodleian Library (MS. Bywater adds. 2), eventually filling-in the gaps to establish \\ an unbroken chain of provenance from the present day back to the creation of the manuscript at the \\ Cistercian abbey of Pontigny within about five years of 1208.

\section{Keywords} \\ Illuminated manuscripts, missal, Bodleian Library, MS. Bywater adds. 2, provenance, Cistercian, Pontigny, \\ thirteenth century, manuscript studies, manuscript, liturgical manuscripts, liturgy
}


Kidd: Medieval Origins

\section{MANUSCRIPT STUDIES \\ A Journal of the Schoenberg Institute for Manuscript Studies}

VOLUME 1, NUMBER 2

(Fall 2016)

Manuscript Studies (ISSN 2381-5329) is published semiannually

by the University of Pennsylvania Press

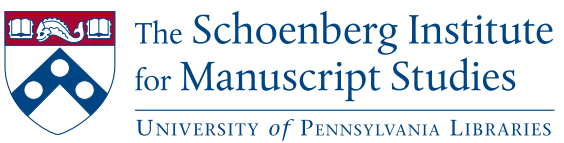




\section{MANUSCRIPT STUDIES}

VOLUME 1, N UMBER 2

(Fall 2016)

\section{ISSN 2381-5329}

Copyright (C) 2016 University of Pennsylvania Libraries and University of Pennsylvania Press. All rights reserved.

Published by the University of Pennsylvania Press, 3905 Spruce Street, Philadelphia, PA 19104.

Printed in the U.S.A. on acid-free paper.

Manuscript Studies brings together scholarship from around the world and across disciplines related to the study of premodern manuscript books and documents, with a special emphasis on the role of digital technologies in advancing manuscript research. Articles for submission should be prepared according to the Chicago Manual of Style, $16^{\text {th }}$ edition, and follow the style guidelines found at http://mss.pennpress.org.

None of the contents of this journal may be reproduced without prior written consent of the University of Pennsylvania Press. Authorization to photocopy is granted by the University of Pennsylvania Press for libraries or other users registered with Copyright Clearance Center (CCC) Transaction Reporting Service, provided that all required fees are verified with CCC and paid directly to CCC, 222 Rosewood Drive, Danvers, MA 01923. This consent does not extend to other kinds of copying for general distribution, for advertising or promotional purposes, for creating new collective works, for database retrieval, or for resale.

\section{SUBSCRIPTION INFORMATION:}

Single issues: $\$ 30$

Print and online subscriptions: Individuals: \$40; Institutions: \$90; Full-time Students: \$30 International subscribers, please add $\$ 18$ per year for shipping.

Online-only subscriptions: Individuals: \$32; Institutions: \$78

Please direct all subscription orders, inquiries, requests for single issues, address changes, and other business communications to Penn Press Journals, 3905 Spruce Street, Philadelphia, PA 19104. Phone: 215-573-1295. Fax: 215-746-3636. Email: journals@pobox.upenn.edu. Prepayment is required. Orders may be charged to MasterCard, Visa, and American Express credit cards. Checks and money orders should be made payable to "University of Pennsylvania Press" and sent to the address printed directly above.

One-year subscriptions are valid January 1 through December 31. Subscriptions received after October 31 in any year become effective the following January 1 . Subscribers joining midyear receive immediately copies of all issues of Manuscript Studies already in print for that year.

Postmaster: send address changes to Penn Press Journals, 3905 Spruce Street, Philadelphia, PA 19104.

Visit Manuscript Studies on the web at mss.pennpress.org. 


\title{
Medieval Origins Revealed by Modern Provenance The Case of the Bywater Missal
}

\author{
Peter Kidd \\ Freelance Researcher
}

he Schoenberg Database of Manuscripts (SDBM) is primarily concerned with the relatively recent provenance of pre-1600 manuL scripts: the vast majority of records in the SBDM relate to the nineteenth and especially the twentieth century. In my experience many students of manuscripts underestimate the importance of recent provenance: some think that the only part of a manuscript's history worth researching is its medieval owners, unless the post-medieval owners are especially notable. The present essay is, I hope, an object lesson in why more recent provenance can be crucially important, and why the SDBM can therefore be an extremely valuable tool when researching the medieval origins of a manuscript: it concerns a volume whose precise medieval origin was determined by an investigation of its nineteenth-century history. ${ }^{1}$

1 Much of the work on which this paper is based was undertaken in the mid-1990s, and versions of it were presented in an Oxford conference on 21-22 June 1997 in honour of A. C. ("Tilly") de la Mare on her retirement as Professor of Palaeography at the University of London, and at a Courtauld Institute Medieval Work in Progress seminar on 8 March 2001, neither of which was published; I am grateful to Lynn Ransom for this opportunity to do so now, in what I hope is an appropriate context. 
Thirty years ago, in 1986, a manuscript missal was bequeathed to the Bodleian Library, Oxford. ${ }^{2}$ Although it came with no prior library catalogue description, it would be inaccurate to say that it was un-described. In fact, I suggest that almost all medieval manuscripts (especially those in, or formerly in, private hands) have been described in print somewhere-often in a bookseller or auction catalogue-but these descriptions often become separated from the books they describe, forcing later researchers to start from scratch. These old catalogues, if they can be traced, may not seem to offer much as descriptions per se by today's standards, because every generation's cataloguing standards and expectations are higher than those of the preceding generation. But however brief and inaccurate an old description may be, it provides at the least one potentially vital piece of information: namely, where the manuscript was at a specific moment in its history. Who owned it prior to that moment may also be stated explicitly, or may be deducible. Sometimes one catalogue contains information that allows one to trace the manuscript back to a previous catalogue, and from there to an earlier one, and so on, but the trail usually fizzles out well before reaching the Middle Ages. Following these chains of ownership is an engagingeven addictive-pastime, but it is not one appreciated by everyone.

In this paper I will first provide a brief overview of this manuscript and the explicit evidence of its twentieth-century provenance. Then some of its textual contents will be explored, to see what they can tell us about its medieval ownership. Finally, it will be demonstrated that the only way to bridge the gap between the medieval and the recent ownership is by working backwards: it will be shown that the nineteenth-century provenance is crucial in leading us to evidence of the precise origin of the book.

2 I prepared a catalogue description that was published online after I left the Library in 2000, at www.bodley.ox.ac.uk/dept/scwmss/wmss/online/medieval/bywater/bywater-adds. html, which is now in need of revision as a result of the work done in preparation of the present paper. I had previously sent a copy to Patricia Stirnemann so that she could include the manuscript in Monique Peyrafort-Huin, with Patricia Stirnemann and Jean-Luc Benoit, La bibliothèque médiévale de l'abbaye de Pontigny (XIIe-XIXe) siècles: histoires, inventaires anciens, manuscrits (Documents, études et répertoires 60; Histoire des bibliothèques médiévale 11; Paris: CNRS, 2001): 551-52 and elsewhere. 


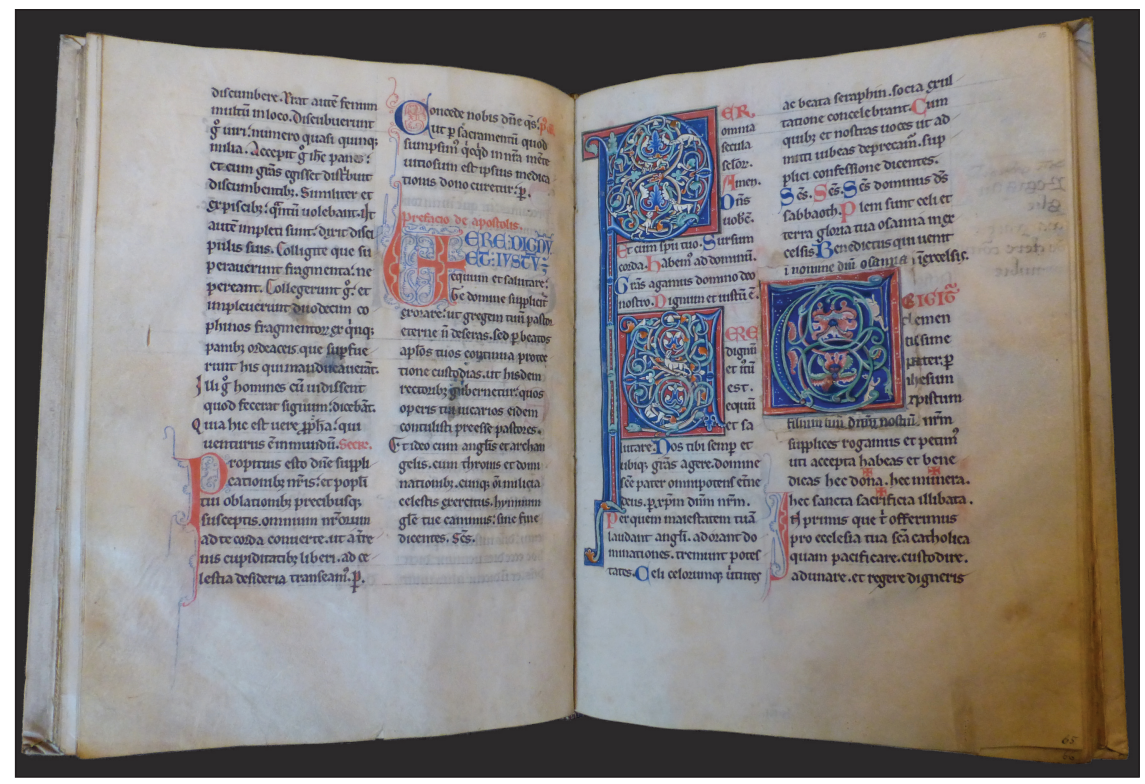

FIGURE 1. Oxford, Bodleian Library, MS. Bywater adds. 2, fols. 64v-65r. Photography by Peter Kidd, by permission of The Bodleian Libraries, Oxford University.

Bodleian Library, MS. Bywater adds. 2 is a fine illuminated missal of 130 parchment leaves, each about $300 \times 200 \mathrm{~mm}$ (about $12 \times 8$ inches) (fig. 1). It was bequeathed to the Bodleian in 1986 by Miss Miriam Robinette "Robin" Tomkinson, a classicist and collector of fine books. It bears a "Bywater adds." shelfmark because she wanted her books and manuscripts to be added to the collections bequeathed to the Bodleian Library early in the century by her great-great-uncle by marriage, Ingram Bywater, who had been subLibrarian of the Bodleian, and Regius Professor of Greek at Oxford, who died in $1914 .^{3}$

Among the only information that was available to me about this missal's origin when I started examining it was a brief note: "Jonathan Alexander looked at the slides of the illuminated pages, and pronounced the manuscript

3 G. Groom, Bodleian Library Record 12 (1986): 145-47; and "Miriam Robinette ('Robin') Tomkinson (1916-1986)," Bodleian Library Record 12 (1987): 253-54. 
'early 13th-cent., probably French, possibly Paris."'4 What more can an examination of the book tell us?

If one is presented with the manuscript, one encounters provenance information as follows:

1. Starting our examination from the outside, which is a very plain nineteenth-century, undecorated, parchment-covered binding over pasteboards, there is an inscription on the spine, giving a title, below the letters or roman numerals "XX[.. .]" and a hole. The inscription is clearly meant to imitate medieval script.

2. Opening the book, we find an oval twentieth-century bookplate, which depicts a bird above "Ex libris / R. Tomkinson," below which is inscribed in pencil "from HT / 51" (fig. 2).

3. Below this is another, earlier-looking, square armorial bookplate with arms, supporters, crest in the form of a coronet, and motto, inscribed in pencil "12th C[entur]y" and next to it "609."

4. On the facing flyleaf, a clipping with a remarkably long printed description of the manuscript is pasted in, apparently from a catalogue in which the manuscript was number 179. The description is exceptionally detailed, and by its length and lack of conventional salesman's hype this does not seem to be a bookseller or auction catalogue.

5. A trace of an inscription is just visible underneath the pasted-in catalogue description, and if this page is illuminated by a strong light from behind, it may be read as "Codex XXV," apparently corresponding to the "XX[...]" at the top of the spine.

6. The paper flyleaves have a watermark that reads "Bath 1824," perhaps a clue to the date and place of the binding.

7. On a following parchment flyleaf is an ink inscription in French, briefly describing the manuscript, which ends with the cryptic letters or initials: "F. A. ${ }^{x "}$ (fig. 3).

4 A note recording this opinion, written by Bruce Barker-Benfield, is inserted into the front of the manuscript as fol. vii. 
Kidd: Medieval Origins

Kidd, Medieval Origins Revealed by Modern Provenance

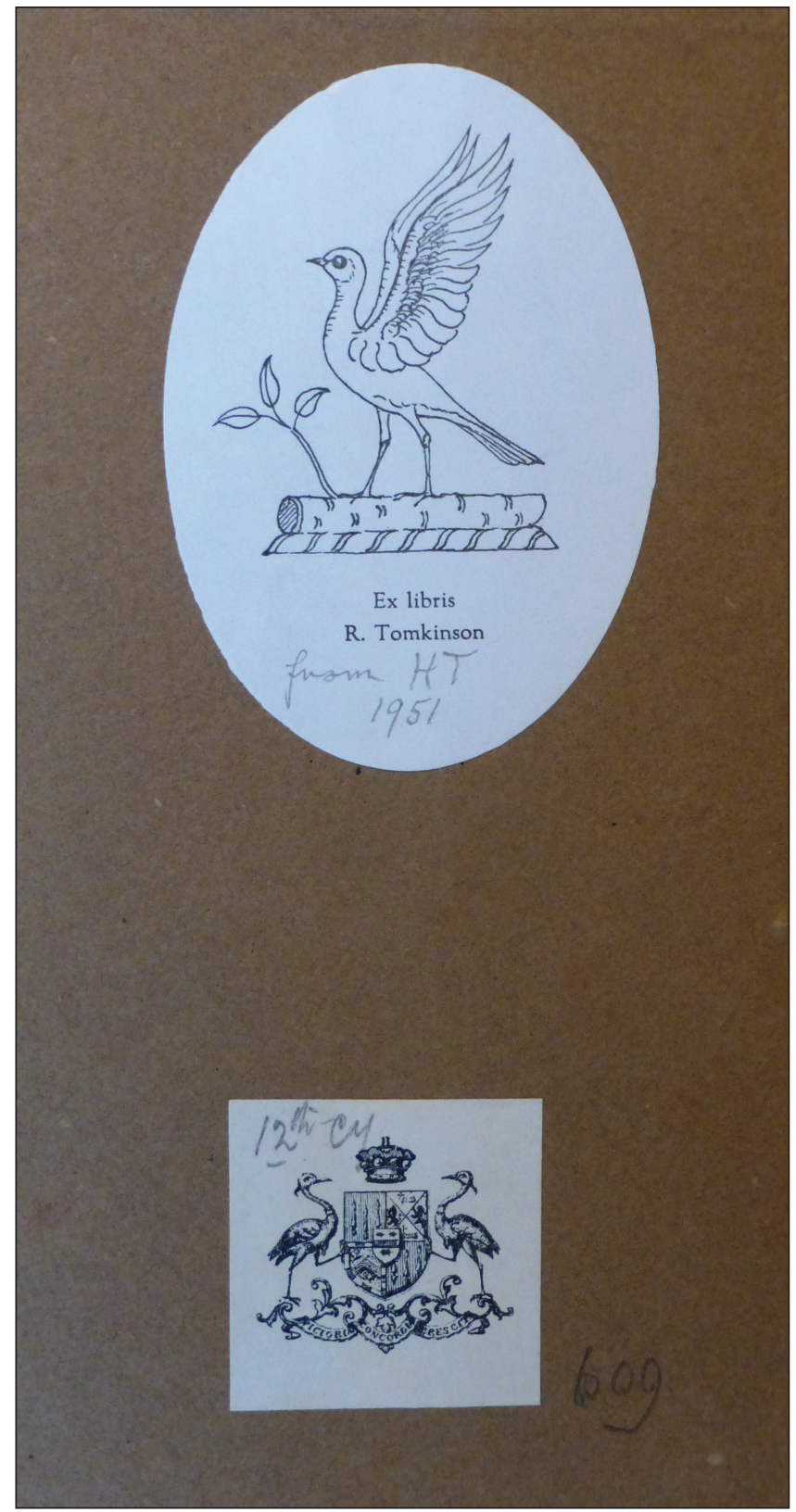

FIGURE 2. Bookplates on front pastedown. Oxford, Bodleian Library, MS. Bywater adds. 2. Photography by Peter Kidd, by permission of The Bodleian Libraries, Oxford University. 


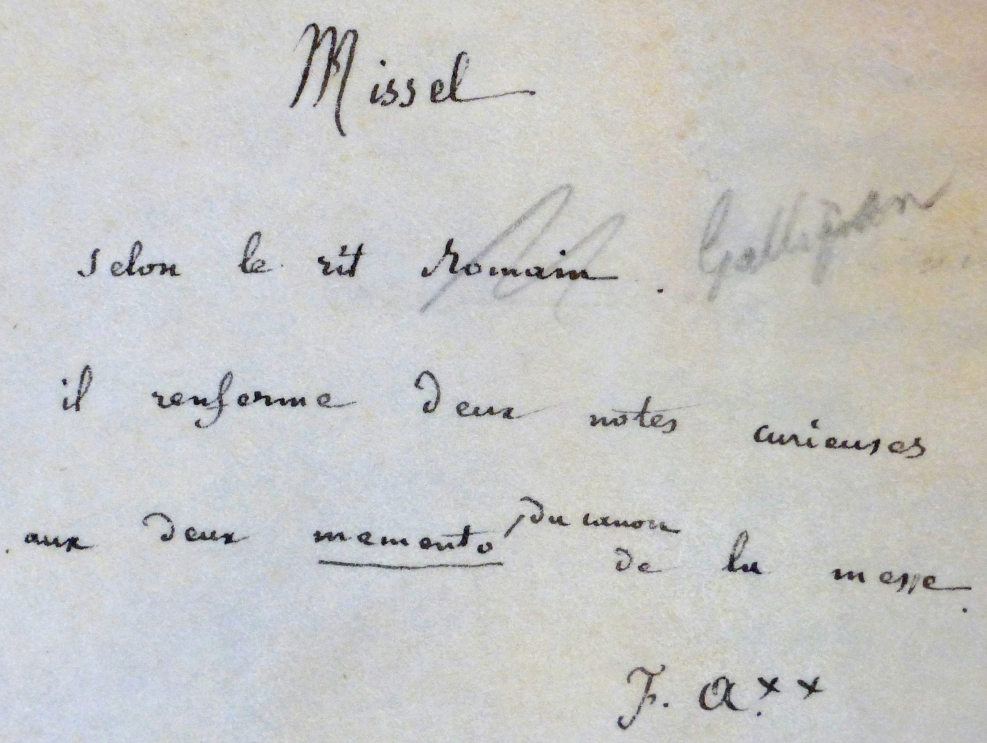

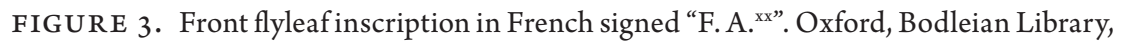
MS. Bywater adds. 2, fol. ix. Photography by Peter Kidd, by permission of The Bodleian Libraries, Oxford University.

8. The first page of the original manuscript and of the main text each have the number " 151 " written in the middle of the top margin, which looks eighteenth century (fig. 4).

Reaching the main body of the book, we find decoration in the "Channel Style" (so-called because it can be found on both sides of the English Channel in the late twelfth and early thirteenth centuries) and the texts of masses for major feasts.

What does this evidence add up to? The easiest part of the provenance to trace is the most recent: the oval bookplate (no. 2 in the list above) is that of Robin Tomkinson, and the pencilled note "from HT 51" suggests that she inherited it from her father, Major Herbert Tomkinson, who died in $1951 .{ }^{5}$

5 On Robin Tomkinson (1916-1986), see Ken Tomkinson, The Tomkinson Story, or, More Damned Tomkinsons (Kidderminster: Kenneth Tomkinson, 1985), 61-63, and on her father Herbert Tomkinson (1873-1951), see 49-57. 


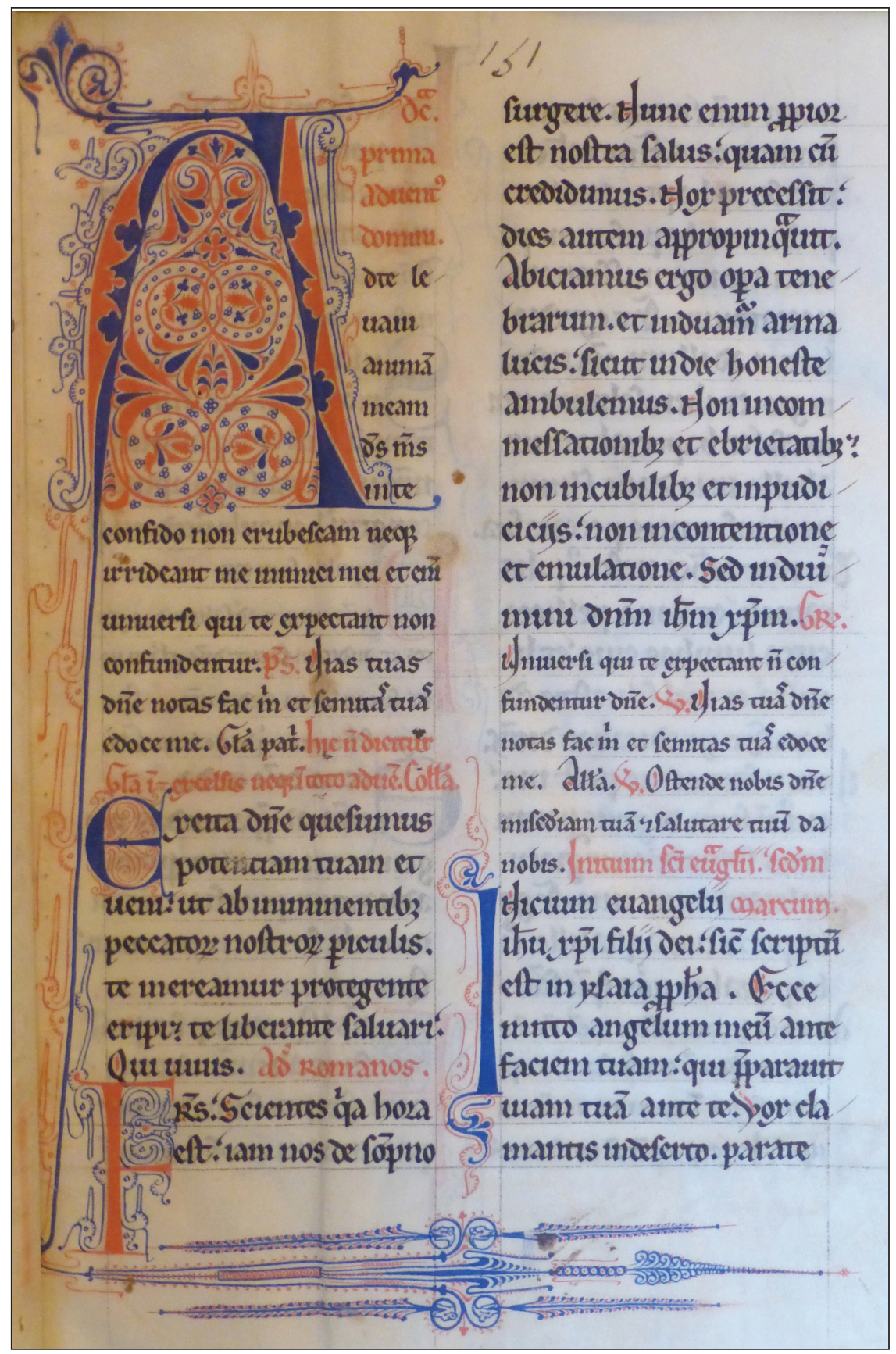

FIGURE 4. Beginning of text, with number "151" in upper margin. Oxford, Bodleian Library, MS. Bywater adds. 2, fol. 4r. Photography by Peter Kidd, by permission of The Bodleian Libraries, Oxford University. 
The SDBM provides the next two previous stages in the provenance: it was sold as part of the important library of Michael Tomkinson (1841-1921), member of the Roxburghe Club, ${ }^{6}$ at Sotheby's on 3 July 1922 and following days, lot 1679, ${ }^{7}$ where it was bought by "Tomkinson" (doubtless Herbert, his eldest son) for $£ 27$. The catalogue description notes that the book is "from the Amherst Library."

A large part of the important library of the Rt. Hon. William Amherst Tyssen-Amherst (1835-1909), ${ }^{9}$ First Baron Amherst of Hackney, was sold at Sotheby's on 24 March 1909 and three following days, in which the Bywater Missal was lot $609 .{ }^{10}$ This explains the number "609" written next to the small armorial bookplate. The privately-printed catalogue of the Amherst library, prepared by Seymour de Ricci and published a few years earlier in 1906, describes the manuscript and includes the Amherst arms, confirming that the bookplate is his. ${ }^{11}$ Lord Amherst formed an important library at his home in Norfolk, rich in medieval manuscripts and early printing, but was forced to sell his library during the last few years of his life in order to cover the losses incurred in an embezzlement scandal involving the solicitor

6 On Michael Tomkinson, see Tomkinson, The Tomkinson Story, 3-45, and "Tomkinson, Michael (1841-1921)," in Oxford Dictionary of National Biography (Oxford: Oxford University Press, 2004), http://www.oxforddnb.com/view/article/48347, accessed 13 June 2016.

7 SDBM_6199.

8 Catalogue of the Extensive and Valuable Library, the Property of the Late Michael Tomkinson, Esq., of Franche Hall, Kidderminster, the Second and Final Portion (London: Sotheby, Wilkinson \& Hodge, 1922).

9 On whom see Alan Bell, "Amherst, William Amherst Tyssen, First Baron Amherst of Hackney (1835-1909)," in Oxford Dictionary of National Biography, http://www.oxforddnb. com/view/article/30402, accessed 31 March 2016; Seymour de Ricci, English Collectors of Book \& Manuscripts (1530-1930) and Their Marks of Ownership (Cambridge: Cambridge University Press, 1930), 165, incorrectly gives the year of his death as 1908, which is surprising, because de Ricci notes of Amherst that "to his kind lessons in English bibliography I owe my earliest interest in a difficult science" (166).

10 Catalogue of the Magnificent Library of Choice and Valuable Books \& Manuscripts the Property of the Rt. Hon. Lord Amberst of Hackney (London: Sotheby, Wilkinson \& Hodge, 1909), SDBM_8247.

11 Seymour de Ricci, A Hand-List of a Collection of Books and Manuscripts Belonging to the Right Hon. Lord Amberst of Hackney at Didlington Hall, Norfolk (for private circulation, Cambridge, 1906), MS 10 on p. 98. 
entrusted with the administration of his estate and trust funds. The Sotheby's annotated catalogue records that the manuscript was bought at the Amherst sale for $£ 64$ by "Thomas K," according to the auctioneer’s copy of the catalogue; "Thomas K" is possibly the result of mishearing or misunderstanding by the auctioneer of "Tomkinson"-perhaps he heard it as "Tom Kinson" and was unsure of the surname.

With the help of the SDBM we have now easily traced the provenance back in an unbroken line more than a century to 1906, but the other pieces of evidence enumerated above do not immediately lend themselves to such easy interpretation. The next step, therefore, is to try to work out the earlier provenance using other means.

A missal is a service book, as most readers will know, containing the texts used by the priest in the performance of the mass. Some of the prayers do not vary from one day to another, and are collected together in the Canon of the Mass, usually found in the middle of a missal. Among these prayers, one is for people such as the pope and the king, one is a prayer for the living, and another is for the dead. In addition to the prayers that remain constant from one mass to the next, there are many that do vary, depending on a number of features. On the one hand, there are masses appropriate for particular feasts in the Church year associated with events in Christ's life that fall on the same date every year, such as Christmas on 25 December and Epiphany on 6 January. On the other hand, there are feasts relating to events in Christ's life that may fall on the same day of the week every year but whose date varies, such as Good Friday and Easter Sunday.

There is another large group of feasts that commemorate saints. Thus, as everyone knows, St. Valentine is commemorated on 14 February, for example. Broadly speaking, the feasts relating to events in the life of Christ are arranged in one section of a missal, the Temporale, while feasts relating to the Virgin Mary, Apostles, and other saints are arranged in a second series, the Sanctorale.

Saints' feasts can be useful in localizing liturgical manuscripts, as many saints were highly venerated in some locations, but not in others. For example, a missal for use in Oxford might treat St. Fridewide as a major feast but omit St. Genevieve, while the reverse would be true in a missal 
made for use in Paris. There are also many grades of importance that a feast can have in a liturgical book, from a brief commemoration to a full Office with up to twelve readings. It thus follows that the contents of a missal for one country, diocese, town, or church will differ to a greater or lesser extent from the contents of a missal made to be used somewhere else. Likewise, feasts of saints can sometimes help in the dating of a liturgical manuscript. Thus, if an English manuscript includes the feast commemorating the death of Thomas Becket in 1170, then it must be later than that date, but if it does not include the feast of his translation (the moving of his relics to a new shrine in Canterbury cathedral) in 1220, then it probably predates this later event. It thus follows that a missal made at one date may differ to a greater or lesser extent from a missal made at an earlier or later date. Study of liturgical details therefore potentially offers a tool for accurately dating and localizing manuscripts, based on sound foundations, in a way that is rarely available to students of other medieval objects such as architecture, panel and glass painting, sculpture, and metalwork. In practice life is not so simple. All too often the presence or absence of saints' feasts, and their relative importance, leads to imprecise or even contradictory conclusions. There is, however, another comparatively little-known method that can be used in the analysis of missals. The liturgical scholar Dom Beyssac developed a system for determining the liturgical "use" of missals, and this was put to good use and publicized by the great cataloguer of medieval liturgical manuscripts in French public libraries, Victor Leroquais.

If you look at the masses in the Temporale for all the Sundays that follow Pentecost, and record the verses that immediately follow the singing of the Alleluia, and then compare the resulting list with the tables in Leroquais' own notebooks, this will usually tell you for which diocese the missal was made. Leroquais provided an example of how this method works in the introduction to his catalogue of sacramentaries and missals in French public libraries. ${ }^{12}$

12 Victor Leroquais, Les Sacramentaires et les missels manuscrits des bibliothèques publiques de France, vol. 1 (Mâcon: Protat, 1924), xxiv-xxv. 
Unfortunately, when one applies the Leroquais test to the Bywater Missal, it does not localize it to a particular church, town, or diocese-nor even to a particular country; the test reveals it to be of Cistercian Use, which does not vary significantly from one Cistercian house to another. (Incidentally, one could also have guessed that this is a Cistercian book by the fact that the scribe uses a typically Cistercian form of punctuation called the punctus flexus, which looks like a figure "7" above a dot-an example is visible in fig. 4, at the end of the ninth line of the second column.)

Such a result from the Leroquais test might seem like a major setback, but it would perhaps be more accurate to think of it as a mixed blessing; while the rigorous uniformity of Cistercian liturgical books means that they can be very difficult to localize, it also means that they are potentially much easier to date, since we know from the Cistercian statutes when various feasts were introduced into the liturgy of the Order.

The Sanctorale in the Bywater Missal contains proper masses only for the major feasts of the liturgical year, namely those with twelve lessons or a higher grading. With even a fairly cursory look, these betray its Cistercian origins by the inclusion, for example, of St. Bernard of Clairvaux among the most important feasts of the year.

All the hard work on the Cistercian statutes has been done and published: it is therefore a simple matter to compare the feasts in the Bywater Missal with lists of feasts and the dates of their adoption by the Cistercians. ${ }^{13}$ Thus, for example, the feast of St. Peter of Tarantaise, which was added to the Cistercian liturgy in 1191, is written by the original scribe, while that of St. William of Bourges, who was added to the liturgy in 1218, is added to the manuscript by a later scribe.

This produces satisfyingly precise results because the latest datable original feast included in the Sanctorale is that of St. Barnabas, whose feast on 11 June was raised to twelve lessons in the Cistercian calendar in 1203, and the earliest datable feast omitted from the original Sanctorale, and subsequently

13 Bernard Backaert, "L'evolution du calendrier cistercien," Collectanea Ordinis Cisterciensium Reformatum 12 (1950): 81-94, 302-16; and 13 (1951): 108-27. 
added, is St. Katherine's, whose feast on 25 November was raised to twelve lessons in the Cistercian calendar in 1214. Thus it is possible to confidently date the missal to within about a decade: from 1203 to 1214.

Newly instituted liturgical feasts are not the only additions to the volume, however, and this was the next most likely source of information about the missal's early history. In the Canon of the Mass are a number of marginal additions in ink, all apparently in hands of the late thirteenth or early fourteenth century, recording the names of various individuals, most of which can be identified.

The words " $\mathrm{d}($ omi)ni regis francie" (now partly erased) have been added in the margin next to the reference to the king in the prayer for the pope, bishop, king, and others (fig. 5). Below this, next to the prayer for the living, have been added " $\mathrm{d}(\mathrm{omi}) \mathrm{ni}$ Edwardi" in a different hand, and immediately below this is, in darker ink, "Regis an- / glie." Below this another similar hand has written "margare[t]e / de clere co(m)itissa / cornubie," and next to the prayer for the dead, over the page, has been added in the margin “[E]dmu(n)di co(m)iti(s) / [c] ornubie," now partially cropped (fig. 6). Below this is an erasure, and below that are "Domini Roberti / cardinalis" and "Adele Regine," both in yet another hand, in greyish ink. Finally, in the margins alongside the mass for the brothers of the congregation, at the end of the volume, a hand of similar date has twice added the phrase "et benefactores." These inscriptions are not idle jottings: all these names and phrases would have been read by the priest as he performed the mass.

Some of the people named in the inscriptions can be identified with confidence. Margaret de Clare, countess of Cornwall, can only be the woman of that name who was born circa 1250 and died in 1312, and Edmund of Cornwall is thus presumably her husband, Edmund of Almain, second earl of Cornwall, ${ }^{14}$ whom she married in 1272, and who was regent for King Edward I from 1286 to 1289, and who died in 1300. As Edmund is recorded among the dead, this inscription must have been written after 1300, and

14 On whom see Douglas Richardson, Plantagenet Ancestry: A Study in Colonial and Medieval Families (2nd ed.; Salt Lake City, UT: Douglas Richardson, 2011), 571-73; and "Edmund of Almain, Second Earl of Cornwall (1249-1300)," in Oxford Dictionary of National Biography, http://www.oxforddnb.com/view/article/8505?docPos=9, accessed 17 June 2016. 


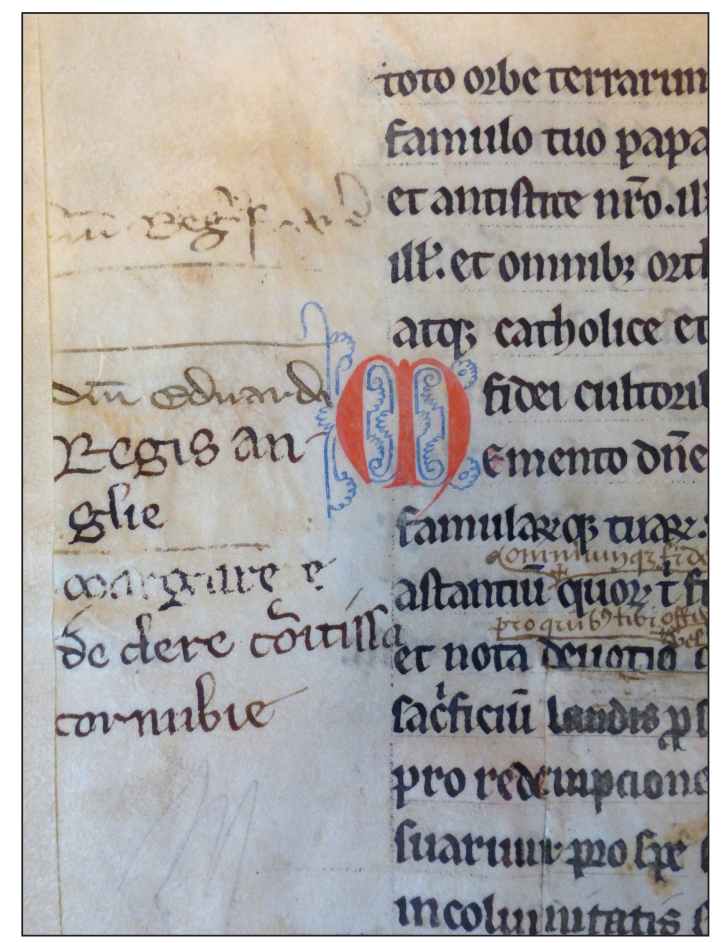

FIGURE 5. Marginal additions next to a prayer for the pope and king, and next to a prayer for the living. Oxford, Bodleian Library, MS. Bywater adds. 2, fol. 65v. Photography by Peter Kidd, by permission of The Bodleian Libraries, Oxford University.

since his wife Margaret is among the living, before 1313. If the inscription for King Edward is contemporary, it could be either Edward I (d. 1307) or Edward II (d. 1327).

"Adele Regine" is potentially the most difficult individual to pin down because there were three French queens of that name before the midfourteenth century, but in fact there is only one likely candidate. Chronologically first was the Capetian queen Adele/Adelaide of Aquitaine, who died in 1006, but she can presumably be dismissed immediately because she lived almost one hundred years too early to have had any connection with the Cistercians. Second there was Adele/Adelaide of Savoy (alias of Maurienne), second wife of Louis VI, who died in 1154 at the Benedictine abbey 


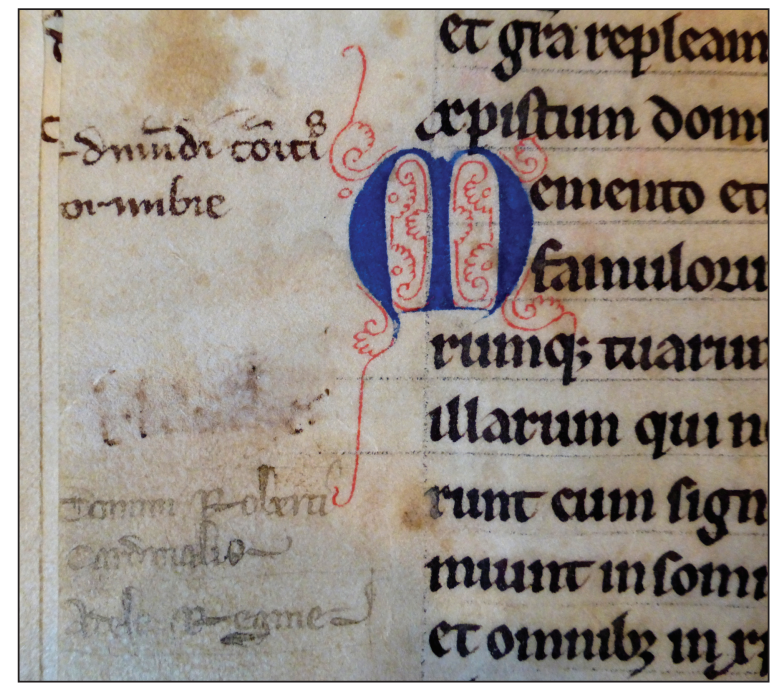

FIGURE 6. Marginal additions next to a prayer for the dead, Oxford, Bodleian Library, MS. Bywater adds. 2, fol. 66v. Photography by Peter Kidd, by permission of The Bodleian Libraries, Oxford University.

of Montmartre, which she and her husband had founded twenty years earlier. Third, there was Adele/Adelaide of Champagne, third wife of Louis VII and mother of the next king, Philip II Augustus. Her father had been largely responsible for funding the rebuilding of the Cistercian abbey of Pontigny; she was herself a major benefactor to the house. So close were her family connections with the abbey that when she died in 1206, she gained the extraordinary distinction of being buried in a fine tomb before the high altar. Of these three candidates, Adele of Champagne is by far the most promising because of her intimate connection with a Cistercian house and because the missal was made within five years before or after her death.

There were also close links between Pontigny and the English. To take just three of the most notable visitors, all archbishops of Canterbury: Thomas Becket stayed there from 1164 to 1166 while in exile, Stephen Langton followed in 1208-1213, and Edmund Rich (alias Edmund of Abingdon) was there in 1240 shortly before his death-and he was buried there. Thomas and Edmund both became saints, and there is a mass in 
honour of each of them in the missal-naturally Thomas' is original, and Edmund's is an addition. St. Edmund was the namesake and patron saint of Edmund of Cornwall who, following a vision, founded and built a chapel in his honor at Abingdon in 1288.

In light of this group of late twelfth- and thirteenth-century archbishops of Canterbury, it is tempting to assume that the Cardinal Robert mentioned in one of the added marginal inscriptions refers to Cardinal Robert Kilwardby, Archbishop of Canterbury, who died in 1278. But if the missal was made for Pontigny, then the Cardinal Robert commemorated among the dead is less likely to be the English Robert Kilwardby, and more likely to be the French Robert who was elected abbot of Pontigny in 1285, became cardinal in 1294, and died in 1305-a date that fits perfectly with the missal's other datable inscriptions. A Pontigny provenance for the missal therefore has much to commend it, but is not certain. Confirmation might be possible by establishing a link from the opposite direction, as it were, by seeing if the missal can be identified in published lists of manuscripts from Pontigny.

Unfortunately it was not possible to find a match in any catalogue or inventory of the Pontigny library. No missals are included in a list of more than two hundred of the Pontigny manuscripts compiled in the thirteenth century, despite the inclusion of other liturgical books. ${ }^{15}$ "Duo volumina Missalium" are mentioned in an inventory of the books and manuscripts drawn up in 1675, but because this reference is so brief neither of them can safely be identified as the present book. ${ }^{16}$ An undated, early eighteenth-

15 The Annotatio librorum Pontiniacensium (Montpellier, Faculté de médecine, MS H 12, fols. 176-82) is printed in the Catalogue général des manuscrits des bibliothèques publiques des départements, vol. 1 (Paris: Imprimerie nationale, 1849), 697-717; and by Peyrafort-Huin, Stirnemann, and Benoit, La bibliothèque médiévale, 246-85.

16 Catalogus catalogorum sive elenchus Mss. codicum qui bactenus reperiuntur in plurimis Europae bibliothecis, desumptus in unum volumen congestus magna cum diligencia ac summo opere Caroli le Tonnellier anno M D C LXXV, Paris, Bibliothèque de l'Arsenal, MS Hist. $839 \mathrm{E}$, fols. 206-11: Catalogus librorum manuscriptorum qui extant in bibliothecae [sic] abbatiae de Pontiniaco Altissiodorensis diocesis, ordinis sancti Bernardi; printed by C. H. Talbot, "Notes on the Library of Pontigny," Analecta sacris ordinis cisterciensis 10 (1954): 106-68 at 112-17; and edited in Peyrafort-Huin, Stirnemann, and Benoit, La bibliothèque médiévale, 291-310. 
century inventory drawn up by Abbé Lebeuf includes "Des missels manuscrits de l'ordre du XII e et XIII e siècle. Il y a grand nombre de tout cela.. ${ }^{17}$ In the more detailed inventory of 322 manuscripts drawn up in 1778 by Jean Depaquy, who was later to become the last abbot of Pontigny, nine missals are recorded ("Missale Cisterciense: 9 exemplaria; in- $4^{\circ}$ "), but again no distinctive features are mentioned that would allow us to say with certainty that any of them is the Bywater Missal. ${ }^{18}$

The abbey was suppressed in 1790, and it was decided to collect together at nearby Sens the contents of the libraries from the various religious houses in that area (a few years later they would be moved again to Auxerre). The following year, a Father Francis Xavier Laire (whom we shall meet again later) was appointed to undertake this task, and he began to draw up new inventories, but it seems that these were not sent to the relevant authorities, so yet another Pontigny inventory was drawn up in 1794 by the commissioners of the Republic. ${ }^{19}$ This lists 380 manuscripts, of which seven were missals and, of these, two could potentially be the Bywater Missal: each is described as a "Missale Pontiniacense; codex membranaceus, XIII. saeculi, in-folio, integer." 20

In examining manuscripts in British libraries with early Pontigny ownership inscriptions, I had noticed that some have inscriptions comparable to that on the first flyleaf of the Bywater Missal, each signed "F.A.x," and in the literature on Pontigny manuscripts, I had read of how a certain Abbé

17 Paris, Bibliothèque nationale de France, MS lat. 10396, fols. 31-32v; edited in PeyrafortHuin, Stirnemann, and Benoit, La bibliothèque médiévale, 313-27, no. 118.

18 Catalogus librorum Mss. bibliothecae Pontiniacensis digestus a f. J. Depaquy Pontiniacensi religioso 1778, Auxerre, Bibliothèque municipale, MS 260', fols. 1-16; printed by Talbot, "Notes on the Library," 127-54; and edited in Peyrafort-Huin, Stirnemann, and Benoit, La bibliothèque médiévale, 342-79 at 370, nos. 252-60.

19 Inventaire de manuscrits de la dite bibliothèque de Pontigny fait par les mêmes commissiares, Auxerre, Bibliothèque municipale, MS 260, fols. 37v-50; printed by Talbot, "Notes on the Library," 143-54; and edited in Peyrafort-Huin, Stirnemann, and Benoit, La bibliothèque médiévale, 417-44.

20 Three others are described as fourteenth century; one more is described as thirteenth century but also specifies the inclusion of extra texts not present in the Bywater Missal; see Peyrafort-Huin, Stirnemann, and Benoit, La bibliothèque médiévale, 439-40. 
Joseph-Félix Allard (1795-1831), ${ }^{21}$ curé of St.-Eustache in Paris, had acquired, by unspecified and perhaps nefarious means, a number of manuscripts from Pontigny and other religious houses in the confusion of the decades after the Revolution. ${ }^{22}$ Comparison with a volume of Allard correspondence at the Bodleian confirmed that both the handwriting and the manner of signing his name were identical. This therefore supported the possibility of a Pontigny origin, but did not prove it. It cannot perhaps be proven that Allard stole any of the many manuscripts from monastic libraries that passed through his hands, but it is significant that in a letter to Sir Thomas Phillipps, Allard says that if Phillipps wants them, he can procure three very fine and valuable manuscripts from the archives at Troyes! ${ }^{13}$

We can work forward from Allard's ownership of the book, and then we will try to work backwards. Allard seems to have brought a number of manuscripts from Pontigny and other religious houses to England between 1824 and 1828, dates that coincide neatly with the 1824 watermark of the paper flyleaves of the Bywater Missal. Two further details lend weight to the idea that Allard might have had the book bound in England in or soon after 1824. The majority of Pontigny manuscripts that retain their medieval bindings are in thick, heavy, wooden boards, which have tended to split due to the way in which metal studs were nailed into them. ${ }^{24}$ In addition, there was a severe tax levied on manuscripts and printed books imported into England in the 1820 s, and this was calculated by weight. The duty was $£ 6$ 10s per hundredweight for bound manuscripts and $£ 5$ per hundredweight

21 Allard is discussed by Talbot, "Notes on the Library," 157-58; and in Peyrafort-Huin, Stirnemann, and Benoit, La bibliothèque médiévale, 229-30; the latter states that fourteen manuscripts have such inscriptions, and she reproduces one of them.

22 Peyrafort-Huin, Stirnemann, and Benoit, La bibliothèque médiévale, 30, suggests that Allard may not have been responsible for removing the manuscripts from the Pontigny collection: he appears to have obtained his St. Martin, Tournai, manuscripts indirectly, through at least one intermediary.

23 “Je n'[uncertain word] alors pas le moyen d'un échange de vous procurer 3 volumes des archives de Troyes en Champagne. Si j'avais en assez d'argent je les aurais gardés pour moi ...” (letter dated 10 August 1830, now Oxford, Bodleian Library, MS. Phillipps-Robinson C. 425, at fol. $15 \mathrm{v}$; this is presumably the letter cited by Talbot, "Notes on the Library," 158 n. 1).

24 Talbot, "Notes on the Library," 110. 
for unbound ones. So if someone wanted to import books into this country, and they were bound in heavy, broken, bindings, it would doubly make financial sense to remove the old bindings, both to reduce the weight, and to qualify for the lower rate of duty. The savings could be used to have them rebound after they had arrived in England. This probably explains the cheap, plain, modern binding of the Bywater Missal.

A number of Pontigny manuscripts were perhaps acquired from Allard by Edward O'Reilly of Dublin (d. 1830), ${ }^{25}$ and were certainly owned later by James Henthorn Todd (1805-1869), Librarian of Trinity College, Dublin. A look at a copy of the catalogue for the first sale of Todd's manuscripts, which took place in London in 1864, ${ }^{26}$ during his lifetime, produces mixed results: the Bywater Missal is indeed there, as lot 179, and on finding this it becomes apparent that it is a cutting from this catalogue that is now pasted to the first flyleaf. It was mentioned above that this description did not seem to be a typical bookseller's or auctioneer's description: it runs to four pages, when four lines would normally suffice, and it is therefore very likely that the detailed descriptions in this catalogue were prepared by Todd himself. (Similarly, Libri had achieved exceptional auction results by writing long, detailed, descriptions of the salient features of some of his own manuscripts, sold five years earlier in 1859. . $^{27}$ However, very unusually, the annotations in the auctioneers' own copy of the catalogue, which record the buyers' names and the prices they bid, stop a few lots before reaching the missal. Perhaps

25 Peyrafort-Huin, Stirnemann, and Benoit, La bibliotbèque médiévale, 231, states that before he died O'Reilly sold some Pontigny manuscripts to Todd, but this seems to be based on a misunderstanding of a footnote in A. N. L. Munby, Phillipps Studies, vol. 3 (Cambridge: Cambridge University Press, 1954), 22 n.1, which concerns manuscripts from St. Martin's, Tournai, not Pontigny, owned successively by Allard, O'Reilly, Todd, and Phillipps. It is certainly suggestive that Todd's Tournai manuscripts came from Allard via O'Reilly, but this does not prove that O'Reilly ever owned Todd's Pontigny-Allard manuscripts.

26 Catalogue of a Valuable Collection of Patristic \& Other Manuscripts on Vellum, which will be Sold by Auction, by Messrs. Sotheby, Wilkinson \& Hodge (London: Sotheby's, 1 June 1864).

27 Catalogue of the Extraordinary Collection of Splendid Manuscripts . . Formed by M. Guglielmo Libri . . which will be Sold by Auction, by Messrs. S. Leigh Sotheby \& John Wilkinson ... 28th of March 1859, and Seven Following Days (London: Sotheby's, 28 March 1859). 
these final lots were withdrawn from the sale or that the auction was, for some unknown reason, stopped before the end.

There was a second sale of Todd's manuscripts five years later, in 1869, after his death, held by a local auctioneer in Dublin, and fortunately the Bodleian has an annotated copy of the catalogue: it reveals that the missal was reoffered in this sale, as lot 1402, and was bought for $£ 90$ by Bernard Quaritch, probably the greatest of all nineteenth-century booksellers. Quaritch offered the manuscript at least three different times that I am aware of, first at $£ 120,{ }^{28}$ later at $£ 90$, and eventually at $£ 50 .{ }^{29}$ This, I am sure, takes us back to Lord Amherst, who was a long-standing client of Bernard Quaritch.

Having established a series of owners from Allard in the early nineteenth century to the present, it still remains to try to work backwards from Allard to the Middle Ages, possibly, though not definitely, to an origin at Pontigny Abbey.

It was noted above that the first original page of the manuscript (fol. 2r) and the first page of the main text (fol. 4r) each have the number "151" written at the top center (fig. 4). It transpired that there was an unpublished numbered inventory of the Pontigny Manuscripts, drawn up by Father Laire in 1791 while they were on temporary deposit at the Bishop's Hall, Auxerre, that includes the following entry: "151. Missale secundum usum ecclesiae Pontiniacensis; in-folio. Manuscript sur vélin du XIVe [sic] siècle, bien conservé." 30

28 Catalogue 257: Catalogue of Oriental Books, Oriental MSS. \& Drawings . . Valuable Books and MSS. Chiefly from the Library of Dr. Todd, Trin. Coll., Dublin (London: Quaritch, January 1870), no. 2470, priced £120.

29 Catalogue 368: Catalogue of Manuscripts, Chiefly Illuminated, and Remarkable as Examples of Antiquity, Calligraphy, and Ornamentation (London: Quaritch, September 1886), no. 35700 , priced $£ 50$; I am grateful to Alex Day of Bernard Quaritch Ltd., who searched the company records on my behalf for details of the sale to Lord Amherst but without success.

30 Index codicum monasterii Pontiniacensis, qualiter in aedes episcopales Autissiodorenses translati fuere anno 1791 de ordine comitatuum gallorum, Besançon, Bibliothèque municipale, MS 1262 M, fols. 49r-70v; this catalogue has since been edited in Peyrafort-Huin, Stirnemann, and Benoit, La bibliotbèque médiévale, 381-416, in which no. 151, the Bywater Missal, appears on p. 403. 
Since, as I have said, Allard had acquired, by whatever means, manuscripts from other religious houses in addition to Pontigny, this insignificantlooking late eighteenth-century inventory number is the only solid piece of evidence that the Bywater Missal was indeed from the library at Pontigny. Thus it is possible to say, with a fair degree of certainty, that we can trace the whereabouts of MS. Bywater adds. 2 from the moment of its creation between 1203 and 1214 until the present day: an almost unbroken chain of ownership spanning just over 800 years, from Pontigny Abbey, to various depots in Sens and Auxerre, to Félix Allard in Paris, to James Todd in Dublin, to Bernard Quaritch in London, to Lord Amherst in Norfolk, to Michael Tomkinson and then his son Herbert Tomkinson both in Kidderminster, to the latter's daughter Robin Tomkinson in Oxfordshire, and finally, after all these travels, to its resting place at the Bodleian Library in Oxford. In other words, the crucial piece of information for tracing the origin of the manuscript is a detail of its eighteenth-century provenance, which in turn was only uncovered by studying the book's nineteenthcentury provenance: precisely the sort of thing for which the Schoenberg Database of Manuscripts is so helpful. 